\title{
The Human Resource Practice Research Based on the Radical Innovative Capability
}

\author{
Jing Bai, Weihao Wang \\ South China University of Technology, Guangzhou, China \\ Email:997278254@qq.com,604476485@qq.com
}

How to cite this paper: Bai, J. and Wang, W.H. (2017) The Human Resource Practice Research Based on the Radical Innovative Capability. Journal of Human Resource and Sustainability Studies, 5, 36-46.

https://doi.org/10.4236/jhrss.2017.51004

Received: May 18, 2016

Accepted: February 24, 2017

Published: February 27, 2017

Copyright $\odot 2017$ by authors and Scientific Research Publishing Inc. This work is licensed under the Creative Commons Attribution International License (CC BY 4.0).

http://creativecommons.org/licenses/by/4.0/

\begin{abstract}
Taking BGI (Beijing Genomics Institute) for example, the essay states, under the current situation-convergence of the Technology and Innovation and enormous critical apparatus heavily relying on import, how one can cooperate with radical innovation ability expressing its charm and kinds of hardworking on human resource behind it. In addition, the essay hopes to bring something meaningful for a great deal of fresh small businesses with the analysis of BGI human resource based on the model of Snell and AMO (ability, motivation \& opportunities).
\end{abstract}

\section{Keywords}

Radical Innovation, Snell Model, AMO Model, BGI

\section{Introduction}

Radical innovation is becoming more and more important for corporations' survival and development with the increasing competitiveness and diverse demands of customers. R\&D will play a greater role in the path to success. How to exploit fresh research to mine potential demands of customers is the genuine bottleneck for countless firms to achieve a bursting increase.

SNELL, which means "strategy-core ability-core human resource" model, could forge a revolution associated with human resource, social resource and organization resource and propel the inner knowledge circulation to hold the core ability of firms. The essay will analyze the strategy of BGI, core competitiveness and human resource to purify the independent innovation ability of BGI [1].

\section{Tech-Innovation Strategy}

\subsection{Background}

On September 9, 1999, with the initiation of genome project, part of China, BGI 
was built in Beijing. BGI has built large-scale sequencing, bioinformatics, health, agriculture breeding, animal cloning microbial technology platforms, since its building, with its leading abilities of sequencing and genome analysis in the world. In 2007, facing the great opportunity of breakthrough on new technology, BGI built the research institute in Shenzhen as well as BGI HK, BGI America, BGI Europe, BGI Japan branches. Since landing Shenzhen, BGI has started to try a new hybrid strategy including R\&D, Technology, Industry. Then, its earnings got a bursting increase at 3 times annually, 400 millions in 2009, more than 1000 millions in 2010.

Since its born, BGI has become the 1st rank group of Gene sequencing industry in the world. On September 9, 1999, BGI joined the human genome project, and responsible for the completing human chromosome 3 short arm area which is about $1 \%$ of the entire human genome sequencing tasks. High-speed growth of BGI truly begins in 2007, BGI not only lead and participate in the international top "one thousand-genome project", "international panda genome project", etc., but also publish a large number of high quality papers in the world's top scientific journals [2].

\subsection{Business Model}

BGI, from the time of landing in Shenzhen, started the implementation of scientific research, technology, industry development "hybrid" strategy, and have made substantial progress in the industry of gene sequencing through innovative products. BGI takes "gene technology makes humanity better" as the slogan, based on the high throughput, low cost learning platform, combining with information and media efforts, collection, storage, discover, analysis, integration of resources and information, integration of wisdom, to build an open, and win-win industry ecosystem, and let gene technology can benefit everyone. Under the theme "task-oriented subject, industries, humans", BGI have finished several high end level gene groups R\&D tasks and published a series of papers on the Nature, Science etc. Now, BGI has got own powerful and united R\&D teams, dedicating to exploit knowledge-intensive health, scale species, economical creatures genes research, plowing in the medicated health industry and modern agriculture industry. BGI also owns huge production ability, just take Down syndrome genes dedication as an example, BGI's got half all over the world. With the more and more advanced detection techs, lower cost, higher demands, BGI's detection programs will hold increasing and there are much more space to mine.

Thus, the reason that BGI have got bursting increase in several years, defeating a number of institutes which have emerged tens of years, is that BGI have explored one new commercial model that heavily relying on market and dedicating to the R\&D. Big platform hold big science, then big industry, then big education. Under this model, Institute always aimed at the 1st rank world level, accepting kinds of talents, create new organization style, buying new equipments and sharing, no positional titles, no amount standard of paper production [3].

Radical innovation aimed at satisfying the demands of emerging market, supplying new production, creating new market, and exploring new distribution 
channels (Danneels, 2002; Jansen et al., 2006). But this style do not run on the old path that focused on the function, but aim at satisfying the demands of new customers and markets, supplying new platform for development in future.

\section{Radical Innovation Ability}

SNELL model hold the prospective that core ability is able to supply customers combinations of techs and skills with special values, owning value, speciality, extension ability and continuous learning ability characteristics. Radical innovation ability is based on the production and continuous techs R\&D ability, is revolutionary ability on the current production and services, is the ability to put creation in a fresh area. Innovation is a huge, long, slow and high cost, risk progress. For the new practitioner, the firms own innovation ability would be signed innovative and means they can go a step further and faster and even get the leading position in the forthcoming competition [4].

Under the idea "decipher the secret of life, compose the industry note", BGI use "three send three lead" innovation style and resources integration ability to draw the R\&D and Operation ability of an innovative cooperation. It is this radical innovation ability that let BGI create own segment and cut the market with it and be the focus of the whole gene sequencing industry.

\subsection{Clear Location}

BGI takes "genes make human better" as vision. Under the clear direct, BGI reshape the genes sequencing and genes information analytics ability with its "task-oriented science, industry and talents" circulation development model.

\subsection{Integrated Production, Education, R\&D}

That BGI is able to become the 3rd satellite company of Shenzhen and the prominent firm in mainland cannot be say not related to its radical innovation ability. BGI erected gene sequencing, mass spectrum, gene engineering, information calculation platforms, and with the demands of R\&D, built human health, creatures, microbes, marines platforms as the core practitioner of national gene warehouse, BGI propels the gene R\&D develop towards the health, environment application and breeding etc.

\subsection{Bi-Fields}

Under the background of convergence of information system and biology technology, BGI chooses the border of IT and BT as its point to force. Taking the demand of scientists as standard, cheap gene sequencing as cut point, implementing massive application of foreign apparatus and conducting a series of innovation on the softwares, absorbing the Cloud management at the same time, BGI have erected "BT+IT" massive sequencing and biology information collection model, forming GOOLE effect. Moreover, BGI got wide and close touch with firms all over the world, dedicating to the human health and science application area [5]. 


\section{Analysis of Human Resource Practice}

The core ability of organization originates from the Intelligence capital, including organization and labour. The human resource of firms creates value for the organization, making company earn continuous customers and markets. The current outcomes related to the radical innovation firms HR practices are kind of detailed [6]. There are some focused on the match problem between the resources and strategy. Jackson \& Schuler (1995) pointed out practice with commitment, participate, creation and elastic matched better with strategy of firm compared to the strict regulated HR practice. Wang, Zang (2005) pointed out that strategic HR management includes inner or outside career plan, employee participate, quality control, target management, group management, culture building, outcome-oriented HR management strategy [7] (Figure 1).

Shipton, West, Dawson, Birdi and Patterson (2006) a vertical research of 22 British production firms turns out that train, recruit, group working, application learning have positive influence on the company [8], as well as total variable salary, bi-department cooperation and techs R\&D (Figure 2).

Beugelsdijk (2008) claims that job autonomy, elastic working hours is good for radical innovation [9].

Jimenez-Jimenez \& Sanz-Valle (2008) states that elastic working design, group working, longtime employing, wide training, career planing, behavior-oriented performance evaluation, biotic salary these practices are good for comprehensive performance of the company [10].

The current popular theory of HR practice is AMO theory, created by Appelbaum (2000), mainly focuses on the ability of employees, intentions, helper three elements which can be used to analyze the HR practice of BGI [11].

\subsection{Recruiting}

Innovative talents. Thick ability of production, education, $\mathrm{R} \& \mathrm{D}$ is powerful support. The high end of subjects and huge industry vision let kinds of talents come to BGI, also, BGI is willing to give a post to these talents only if he is talented. Many employees are still looks like students and it is them that create the miracle of BGI [12]. In 2013, BGI published 196 papers on SCI, 12 on Nature, 3 on Nature side. The young employees are the main propulsion. In addition, there are also some "big fishes" in industry will come to BGI work without salary [13].

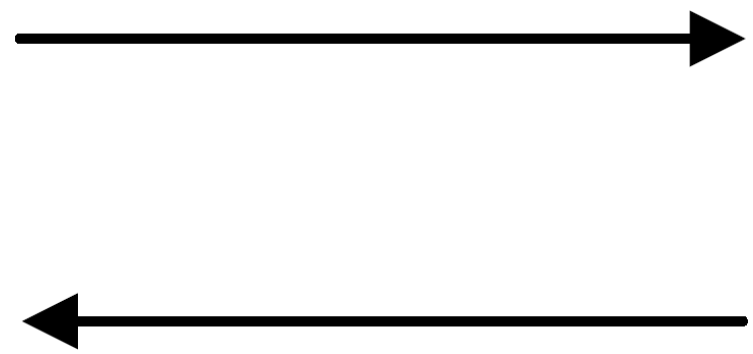

Figure 1. Three send \& three lead. 


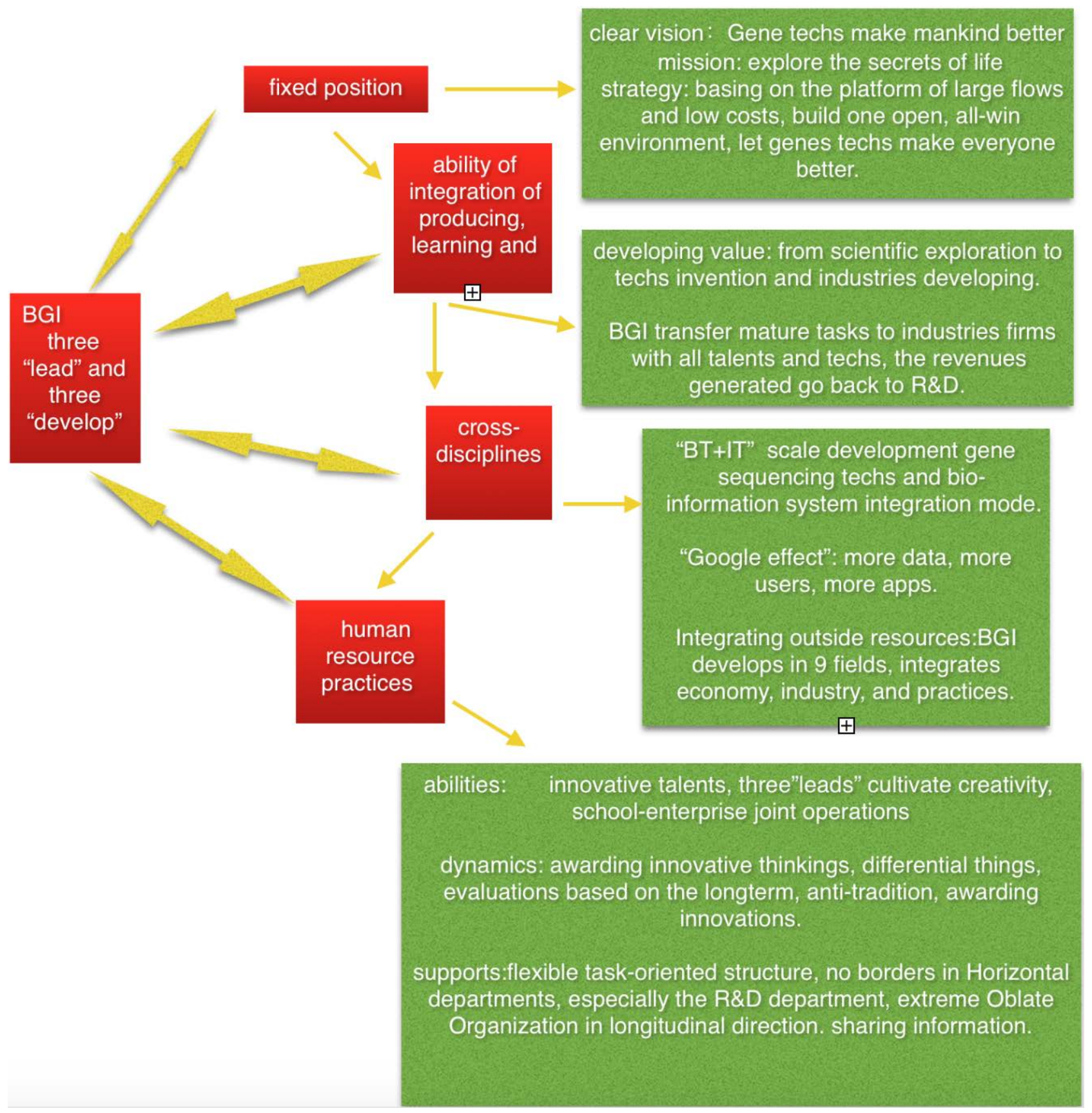

Figure 2. Maps about the supports of HR practices to innovational abilities of BGI.

\subsection{Training}

"Three lead" cultivate the creativity. BGI takes leading science, leading industry, leading talents as theme, and cultivate the intelligence team to support radical innovation ability [14]. In BGI, there is a huge integrated teaching system that is not classified to anyone. The elimination rate is at $15 \%-20 \%$ could promote the competition among employees [15]. Because of the limited money, reveling talents is difficult but BGI could assure that use talents in justice and ability 1st, degree 2nd. Therefore, a number of geeks assembly in BGI.

United cultivate under firms and schools. Conducting double teaching model 
by inner and outside school. BGI gets good touch with PU, WU, SCUT etc. Adopting " $2.5+1.5+\mathrm{X}$ " or " $3+1+\mathrm{X}$ " mode to cultivate masters or Doctorals [16]. Besides, BGI keeps touch with HKU, University of Copenhagen for the outside school plan. One project, BGI built it with HKU, that focused on the Gene trans-group innovation department plans to cultivate Genomics and proteomics talents in future, and the mass of it has grown to thousands of people since several one when it is built [17].

\subsection{Rewards and Evolution}

As a breakthrough innovation enterprises, to innovation as the bellwether of incentives and culture is the best driving factors. Genomics on reward is also do STH unconventional or unorthodox, reveal unique industrialized management thinking. Such as the girls shave their heads, Wang Jianli gave her 8000 dollars award; Investigators will cut their hair "huada" 2 words, dyed my hair red got Wang Jian encouragement "provocation". In genomics staff incentives for innovative thinking will be vigorously [18].

Genomics as an institution outside the system, only to have the double values of scientific and economic results, to ensure its own survival and development. They don't use paper oriented "baton", the worker's salary, position is not linked to the paper, but to encourage and support scientific and technological personnel cooperation, joint, do big project, output value of the fruit [19]. To cope with the rapid development of planning, genomics from a large number of old and new employees training excellent talent and screening, and puts forward the concept "copper brown" in the first place. All new employees shall be through a strict "copper los check can mount guard work, older workers must be through the post related" copper los assessment "to continue to have on the original post job opportunities or promotion opportunities, maximum limit to ensure the talent team of high, refined, pointed state" (Figure 3).

\subsection{Organization Culture}

BGI is to create the traditional culture, Wang Jian only allowing employees to call him Wang manager instead of Wang teacher. No one in the company to wear a suit, no tie, and dressed themselves into American NBA star; No one has a separate office, Wang Jian sits together with staff members in the same location. Wang Jian frees the thoughts and behaviors of employees with his powerful style and let them start from daily behavior preheating innovation everywhere [16]. Such as the girls shave their heads, Wang Jianli gave her 8000 dollars award at once; Investigators will cut their hair into "huada" 2 words, dyed hair red means "provocation".

\subsection{Organization Design}

On the organizational governance, BGI pursues simplicity. There is no boundary between lateral and department. BGI gene group, the highest level of BGI, has 

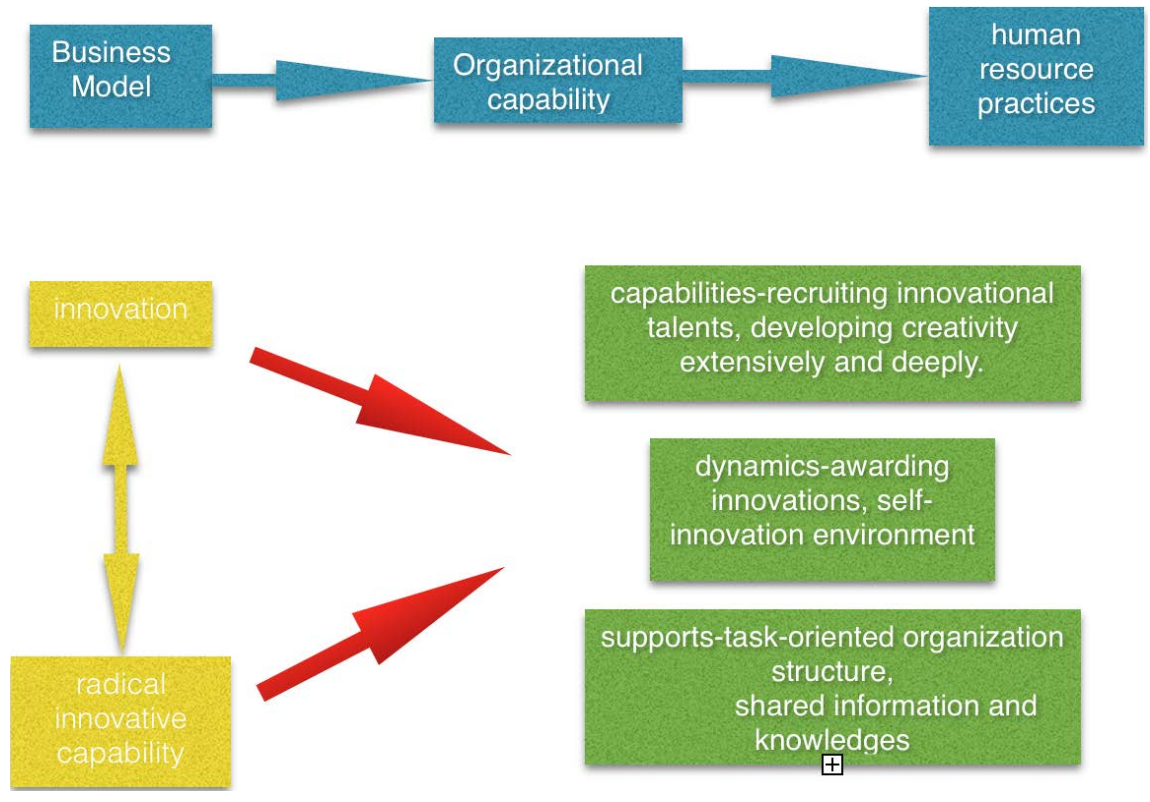

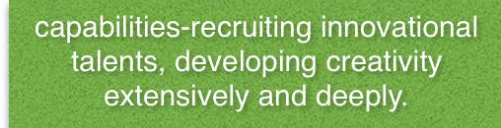

dynamics-awarding

innovations, self-

innovation environment

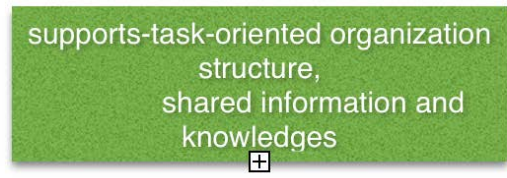

Figure 3. Summary maps about human resource of radical innovational cooperations.

formed production, the integration of the entities, enterprises and the organization system [17]. Two platforms based on the experiment and calculation, to perfect science and technology, links, industry and the support system, respectively, set up the BGI R\&D, BGI technology service Ltd., BGI health technology Ltd., BGI institute etc.

BGI institute has set up a technical development team, covering all of the research scope of the project, studies the basic core technology development, the collection of scientific research in the world trend and the latest research techniques, and then provided to the institute for practice made up of ten people. Now platform is vertically divided into different group according to the fields. And put a lot of manager of Marketing Department staffs in collecting information on the industry needs, feedbacks to the scientific research personnel, to choose suitable and feasible project to do. So listen to the market demand point and possible effect after project [16].

\subsection{Communication}

All employees working in a large system platform, especially the research and development department, if any employee of the other groups are interested in the project, they can apply to join. Longitudinal, extremely flat, and eliminated the word "eapfrog report", let staff communicate more smoothly. As a typical representative of BGI, radical innovation ability is a creative talent shape "factory". The cultivation of the young people here are endowed with more opportunities and innovative culture, unique business integration organization system and flat organization structure form the breakthrough innovation ability type energy pool.

Publicly in BGI has a set of online teaching system, no secret, anyone can learn. In an atmosphere of knowledge and information sharing, R\&D staff con- 
tinually generates new ideas and new product design, made one and one innovations on the borders, thus defending the fortress of radical innovation ability [16].

\section{Revelations}

Radical innovation enterprises should first have a strong radical innovation ability, and have the necessary basic elements for that [16].

In addition, the advantages of this kind of enterprises mainly expresses in the following three aspects: find and snare the innovation idea in greater fields and space, implement more actively, and take a good use of business model innovation, own innovative culture. Nearly half of the radical innovation enterprises said, in the past three years, more than $30 \%$ of the sales comes from innovation achievements, equal to twice the average level of all the innovative firms. Under the influence of many factors, the demand requirement for enterprise innovation is increasing [20]. In the eyes of business leaders, the demand to realize radical innovation is also growing. But the enterprises being ready to get radical innovation is few.

Under the in-depth analysis of the HR practice within the large genetic radical innovation ability, we generalize that, radical type innovative enterprise human resource practice attaches great importance to the staff's innovation ability, through the core talent recruitment research and development innovation, and pay attention to the differential compensation management and long-term guidance with the combination of examination, to stimulate employee creativity, so as to realize the radical enterprise innovation ability. This practice focuses on specific human resources practice is embodied in recruiting talent with creativity, pay attention to broaden the employee training innovative vision, encourage long-term oriented, pay attention to team oriented and employee development incentives, pay competitive, free cultural atmosphere of independent innovation, the structure of the flexible system of the project department, according to these we paint the innovative strategy under the guidance of human resource model for radical innovation ability to support the blueprint.

1) Recruiting the innovative talents

GI is extremely serious to R\&D talents and not only dare to use young innovative talents, but also do not follow the routine on the degree, the only standard is innovative talents. Like Zhao Bowen, a group of brilliant young innovative subject leaders, BGI's attention for talents creates a final excellent industrialization of scientific research projects. As radical innovation enterprise, BGI put attention on R\&D talents and it is a key factor in an indispensable part of the technical innovation, so if one firm want to develop its own radical innovation core ability more effectively, it must be from the source control and pursuit of the most creative talents.

2) Cultivate creativity widely and deeply

BGI, based on its strong scientific research strength, through the joint between colleges cultivate and "three fa three dai" mode to shape innovation conscious- 
ness and research and development strength of R\&D personnel, then translate into their own innovation strength. For those small businesses who are pursuing to promote the techs innovation levels, the joint cultivation mode is a good method to mine the great star.

3) Reward the creativities

As a breakthrough innovation enterprise, the achievements of technology innovation are crucial, so innovation R\&D staff play an irreplaceable role. Genomics is deeply aware of this, on the rewards innovation power is strong, the establishment of a highly competitive compensation system, emphasize innovation oriented appraisal system, long-term incentive oriented, attaches great importance to the employees for the long-term development of the enterprise performance evaluation. Breakthrough innovation enterprise innovation on reward tilt is the norm, differentiation tilt to innovation personnel salary, bonus for innovation is a respect for the breakthrough innovation and motivation. Radical innovative firms could explore kinds of channels, broken the vision of employees, supply more opportunities of training and career planning.

4) Making creative atmosphere

BGI holds the vision that "genes make human better" and recruit more and more talents under his command, in this big family, free autonomous atmosphere creates more power for independent innovation. That do something unconventional or unorthodox is out of reach on the degree of the traditional thinking. As a radical innovation enterprise, independent innovation culture should be deeply rooted in the minds of employees, not only as a strong appeal for talents, but also as a shield.

5) Task-oriented

Simplified task-oriented organization structure, easy job, elastic working hours, highly autonomous atmosphere, all of these will activate the consciousness of employees. The task-oriented structure matches well with its "three day three fa" mode, and united production, education, R\&D together powerfully. Through the effective management on the program team, strength the consciousness of employees, let the edge effect of knowledge complementarity easier to $R \& D$ innovation, to cultivate innovation ability.

6) Sharing

Smooth Communication is powerful shield to generate knowledge and product, the sharing of knowledge and information is Catalyst. radical innovation enterprises open online knowledge sharing system will greatly enhance the knowledge innovation ability and efficiency.

\section{Conclusion}

Under the guide of self-directed innovation products, radical innovation enterprises enhance its own technology R\&D strength, and lead the market through technical innovation. BGI actually is an excellent example of what others can do to become one outstanding company. However, all of these need innovative talents and innovation competitiveness, innovation culture roots, and the cultiva- 
tion of the innovation atmosphere. In addition, under the very background of bursting information and big data, probability of anything would increase in a geometrical way. Thus it would be a great role that HR practice will play in the commercial world.

\section{References}

[1] Lepak, D.P. and Snell, S.A. (2002) Examining the Human Resource Architecture: The Relationships among Human Capital, Employment, and Human Resource Configurations. Journal of Management, 28, 517-543. https://doi.org/10.1177/014920630202800403

[2] Collins, C.J. and Smith, K.G. (2006) Knowledge Exchange and Combination: The Role of Human Resource Practices in the Performance of High Technology Firms. Academy of Management Journal, 49, 544-560. https://doi.org/10.5465/AMJ.2006.21794671

[3] Chandy, R.K. and Tellis, G.J. (2000) The Incumbent's Curse? Incumbency, Radical Product Innovation. Journal of Marketing, 64, 1-17. https://doi.org/10.1509/jmkg.64.3.1.18033

[4] Gatignon, H., Tushman, M.L., Smith, W., et al. (2004) A Structural Approach to Assessing Innovation: Construct Development of Innovation Locus,type and Characteristics. Management Science, 48, 1103-1123.

https://doi.org/10.1287/mnsc.48.9.1103.174

[5] Subramaniam, M. and Youndt, M.A. (2005) The Influence of Intellectual Capital on the types of Innovative Capabilities. Academy of Management Journal, 48, 450-463. https://doi.org/10.5465/AMJ.2005.17407911

[6] Mitchell, G.R. (2000) Industrial R\&D Strategy for the Early 21st Century. Research Technology Management, 43, 31-35.

[7] Teece, D.J. (1998) Capturing Knowledge Asset. The New Economy Market for Know-How and Intangible Assets. California Management Review, 40, 55-79. https://doi.org/10.2307/41165943

[8] Merrifie, U.D.B. (2000) Changing Nature of Competitive Advantage Research. Technology Management, 43, 41-45.

[9] Berthon, P., Hulbert, J. and Pitt, L. (1999) To Serve or to Create? Strategic Orientations towards Customers and Innovation. California Management, 58.

[10] Christensen, C.M. and Bower, J.L. (1996) Customer Power, Strategic Investment and the Failure of Leading Firms. Strategic Management Journal, 17, 197-218. https://doi.org/10.1002/(SICI)1097-0266(199603)17:3<197::AID-SMJ804>3.0.CO;2-U

[11] Danneels, E. (2002) The Dynamics of Product Innovation and Firm Competences. Strategic Management Journal, 23, 1095-1121. https://doi.org/10.1002/smj.275

[12] Danneels, E. (2004) Disruptive Technology Reconsidered: A Critique and Research Agenda. Journal of Product Innovation Management, 21, 246-258. https://doi.org/10.1111/j.0737-6782.2004.00076.x

[13] Jansen, J.J.P., Van Den Bosch, F.A.J. and Volberda, H.W. (2006) Exploratory Innovation, Exploitative Innovation, and Performance: Effects of Organizational Antecedents and Environmental Moderators. Management Science, 52, 1661-1674. https://doi.org/10.1287/mnsc.1060.0576

[14] Lewin, A.Y., Long, C.P. and Carroll, T.N. (1999) The Coevolution of New Organizational Forms. Organization Science, 10, 535-550.

https://doi.org/10.1287/orsc.10.5.535 
[15] Narver, J.C., Slater, S.F. and MacLachan, D.L. (2004) Response and Proactive Market Orientation and New-Product Success. Journal of Product Innovation Management, 21, 334-347. https://doi.org/10.1111/j.0737-6782.2004.00086.x

[16] Ma, M. (2007) Human Resource Developing and Management of Innovational Firms. Science and Industries, No. 8, 47-50.

[17] Wang, H.G. and Fan, L.H, (2012) Relavations (from BGI) about the Reform of Applicational Research Institutes. China Science Forum, No. 7, 7-10.

[18] Qian, W. (2011) BGI: Worldfactory of Genes Sequencing. China Newsweek, No. 26, 63-65.

[19] Zhang, F. (2008) The Research about the Influence on the Innovation Capability Brought by Human Resource Practices. Master's Thesis, Zhejiang University, Hangzhou.

[20] Xu, G. (2013) Analysis of Human Resource Practices with Innovative StrategiesOriented. Heilongjiang Science Information, No. 7, 175.

Submit or recommend next manuscript to SCIRP and we will provide best service for you:

Accepting pre-submission inquiries through Email, Facebook, LinkedIn, Twitter, etc. A wide selection of journals (inclusive of 9 subjects, more than 200 journals)

Providing 24-hour high-quality service

User-friendly online submission system

Fair and swift peer-review system

Efficient typesetting and proofreading procedure

Display of the result of downloads and visits, as well as the number of cited articles

Maximum dissemination of your research work

Submit your manuscript at: http://papersubmission.scirp.org/

Or contact jhrss@scirp.org 